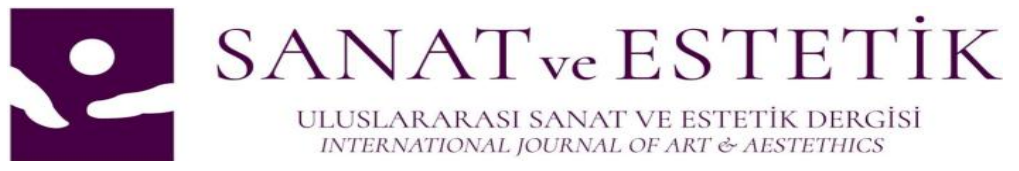

Uluslararası Sanat ve Estetik Dergisi Y11:3, Say1:4, Haziran 2020

Yayın Geliș Tarihi / ArticleArrivalDate

10.06.2020
Yayınlanma Tarihi / ThePublicationDate

30.06 .2020

Öğr. Gör. Rasim Bağırlı

Selçuk Üniversitesi Güzel Sanatlar Fakültesi Seramik Bölümü

rasimbagirli@ selcuk.edu.tr ORCID: 0000-0001-8467-9820

\title{
ÇAĞDAŞ SERAMIK SANATINDA BİR İFADE BİÇİMİ OLARAK SERİGRAFİ BASKI TEKNIĞGI VE BİREYSEL UYGULAMALAR
}

\section{$\ddot{O} \mathbf{z}$}

Seramiğin tarihsel süreci değerlendirildiğinde seramik, insanoğlunun hem günlük kullanım nesnesi olarak hem de bireysel olarak kendini ifade edebildiği bir alan olarak karşımızda durmaktadır. En temel tanımlama ile hammaddesi kil olan ve pişirildiği zaman dayanıklılık kazanan bu malzemenin tarihi, insanlığın yerleşik yaşama geçmesi ile ilişkilendirilir. Seramiğin teknik bir malzeme olarak endüstride kullanımı ve plastik bir malzeme olarak da sanatçıya ilham veren özgün uygulamalarda kullanımı söz konusudur.

Çağdaş sanat farklı sanat disiplinlerinin bir arada kullanımına sıklıkla gözlenmektedir. Çağdaş seramik sanatı da aynı anlayışla farklı disiplinler ile etkileşime girmektedir. Baskı resim alanı bu etkilenme alanlarından birini oluşturur. Bu çalışma, zamansal süreç içerisinde geleneksel ve dekoratif kimliğinden uzaklaşmış olan çağdaş seramik sanatında bir ifade biçimi olarak kullanılan serigrafi baskı tekniği ile üretilen özgün üretimlerin sanatçıya ve izleyiciye yeni bakış açıları sunması üzerine odaklanmıştır. Birçok tanımın ve anlamlandırmanın yanı sıra çağdaş seramik sanatında uygulama alanı olarak serigrafinin kullanımı akademisyen/sanatçı Rasim Bağırlı’nın İzler/İzlenimler Serisi özelinde tasarım, uygulama ve fırınlama çalışmalarını yürüttügü seramik uygulamaları açısından değerlendirilmiştir. 


\section{ÇAĞDAŞ SERAMIKK SANATINDA BİR İFADE BİÇİMİ OLARAK SERİGRAFİ BASKI TEKNIGĞI VE BİREYSEL UYGULAMALAR}

Anahtar Kelimeler: Seramik, çağdaş seramik sanatı, baskıresim, serigrafi.

\section{AS A FORM OF EXPRESSION IN CONTEMPORARY CERAMIC ARTSERIGRAPHY PRINTING TECHNIQUES AND INDIVIDUAL APPLICATIONS}

\section{Abstract}

When the historical process of ceramics is evaluated, ceramic stands before us both as an object of daily useand as an area where it can express itself individually. With the most basic definition, thehistory of this material, the raw material of which is durable when it is cooked, is associated with the transition of humanity to the settled life. The use of ceramics as a technical material in industryand as a plastic material are used in original applications that inspire the artist.

Contemporary art is frequently observed to be used together in different art disciplines. Contemporary ceramic art also interacts with different disciplines with the same understanding. The print image area is one of these affected areas. This study focused on presenting new perspectives to the artist and the audience by theoriginal productions produced by the screenprinting technique, which is used as a form of expression in contemporary ceramic art, which has moved away from its traditional and decorative identity within the temporal process. In addition to many definitions and interpretations, theuse of screenprinting as a field of application in contemporary ceramic art has been evaluated in terms of ceramic applications in whichacademician / artist Rasim Bağırlı carries out design, application and baking works in theTraces / Impressions Series.

Keywords: Ceramics, ContemporaryCeramic Art, Printmaking, Serigraphy.

\section{Giriş}

Seramiğin bulunuşunun insanlık tarihi kadar eski olduğunu arkeolojik belge niteliği taşıyan kalıntılar aracılığı ile söylemek mümkündür. İnsanlığın avc1-toplayıcı yaşamdan yerleşik hayata geçişi sonucu ortaya çıktığı düşünülen seramik, tarihsel süreç açısından kesintisiz bir biçimde günümüze kadar gelmiştir. Sürekli bir değişim ve gelişim içinde olan seramik, teknolojik olanakların oldukça geliştiği günümüzde hem endüstriyel hem de plastik sanatların bir dalı olarak varlığını sürdürmektedir. Değişen toplumsal dinamikler ve gelişen teknoloji sayesinde sanatın her alanında yaşanan dönüşümler seramik temelli alanlarda da yaşanmıştır. 


\section{ÇAĞDAŞ SERAMIKK SANATINDA BİR İFADE BİÇİMİ OLARAK SERİGRAFİ BASKI TEKNIGĞI VE BİREYSEL UYGULAMALAR}

Özellikle bu toplumsal yaşam döngüsünün kültürel yap1 üzerindeki en önemli etkilerinden birisi tartışmasız olarak Endüstri Devrimi'dir. Endüstri Devrimi'nin toplumsal ve kültürel yansımalarının bir sonucu/başlangıcı olarak bilim ve sanat alanında farklılaşan ilkeler çerçevesinde şekillenen yeni düşünce sistemi sayesinde seramik sanatında, endüstrisinde ve eğitiminde çağdaş bir anlayış benimsenmiştir. Bu ekonomik, sosyal ve kültürel süreç kapsamında Çağdaş Seramik Sanatı; Arts and Crafts hareketi ve Bauhaus Ekolü'nden etkilenmiştir (Çevik, 2015: 77).

\section{Seramik ve Çağdaş Seramik Sanatı}

Ana hammaddesi kil olan seramik, insan zekâsının bir sonucu olarak ortaya çıkan, günlük yaşamda, ileri teknoloji ürünlerinde ve en önemlisi sanat alanında kullanılan oldukça önemli bir malzemedir. En basit tanımı ile kilin su ile yoğrularak plastiklik özelliği kazanmasından sonra belli yöntemlerle kullanım amacına göre şekillendirilip, kurutulup ve son olarak dayanıklılık kazanıncaya kadar pişirilmesidir (Özel, 2007: 130). Genel bir tanımlama ile seramik; “organik olmayan malzemelerin oluşturduğu bileşimlerin, çeşitli yöntemler ile şekil verildikten sonra, sırlanarak ve ya sırlanmayarak sertleşip dayanıklılık kazanmasına varacak kadar pişirilmesi bilim ve teknolojisidir” (Arcasoy, 1998:1). Seramiğin ilk hammaddesi balçık adı ile tanınan çok ince taneli koyuca kıvamlı çamur birikintileridir. Tarihteki ilk seramik kaplar, balçık ile sıvanmış sepetten oluşan kaplardır. Bu balçıkla sıvalı sepetlerin ateşle buluşup sertlik kazanmalarının sonucu oluşan kaplar, kullanışlı kap kaçakları oluşturmuştur (Yardımcı, 1993: 3).

Seramik hammaddelerinin pişirme işlemleri sonucunda dayanıklılık kazanma özelliği, seramiği antik dönemden günümüze kadar insan yaşamın neredeyse her alanında vazgeçilmez bir malzeme olarak kullanmasına olanak tanımıştır. Seramik bünyeler, seramiğin zamana ve doğa koşullarına karşın yüksek direnç göstermesi nedeni ile hakkında yazılı belgelerin olmadığı antik uygarlıklar döneminde bile insanların yaşayış biçimleri, dinsel inanışları ve toplumsal süreçleri hakkında detaylı ve etkili bilgiler edinebilmemizi sağlayacak arkeolojik belge niteliği taşımaktadır (Çevik, 2010: 36). İnsanoğlunun günlük temel ihtiyaçlarından doğan seramik; uygarlığın erken dönemlerinde günlük hayata girmiş ve günümüze kadar kesintisiz olarak kullanımını sürdürmüştür. Seramik üretimler günlük hayata yardımcı taşıma ve saklama kaplarından, dini temalı adak heykelciklerine, yapı malzemesinden, oyuncaklara, süs eşyalarından, mezarlara, tabletlere kadar büyük bir çeşitlilik göstermiştir (Erman, 2019:144). 


\section{ÇAĞDAŞ SERAMIKK SANATINDA BİR İFADE BİÇİMİ OLARAK SERİGRAFİ BASKI TEKNIGĞI VE BİREYSEL UYGULAMALAR}

Seramik, insanoğlunun en eski ifade biçimlerinden biridir. Kilin kuruduğunda bile kolay şekillendirilebilen ve yaşken de farklı objelerle sıvanıp kullanılabilen bir malzeme olması, bu malzemenin kolaylıkla kullanılmasını sağlamıştır. Zaman içerisinde farklı araç ve gereçler kullanılarak şekillendirilen seramik malzeme, son yıllarda dijital araçlarla da şekillendirilebilir hale gelmiştir (Özgüven, 2017: 2).

Dönemsel açıdan bakılacak olursa endüstriyel olanakların hızla gelişmesi sonucu kullanıma yönelik, seri üretim seramikler sıklıkla karşımıza çıkmaktadır. Seramik, üretimindeki bu çeşitlilik sayesinde hem sanatsal hem de bilimsel üretim alanlarında iki veya üç boyutlu uygulamalara olanak sağlamıştır. Seramiğin kendini "Sanat Seramiği” olarak 20. yüzyı1 içerisinde kabul ettirmesi diğer plastik sanat dallarına göre yeni bir disiplin olarak nitelendirilmesinin nedenidir. "Sanat Seramiği" olarak adlandırılan bu çalışmalar heykel sanatının biçim ve içeriğinin yanında resim sanatının da renk öğesini bünyesinde barındırmaktadır (Sönmez, 2002: 178-179).Sanat dalı yanında bilim dalı da olan seramik, günümüz teknolojisi ile inanılmaz olanaklar sunmaktadır. En yaygın bilineni uzay araçlarının dışının yüksek 1sıya dayanıklı seramik yüzeyle kaplanmasıdır. Yoksa uzay dönüşü atmosfere çarpan kapsülün bu hızla almış olduğu ısının enerjisi onu yakabilirdi. Günümüzde bükülebilen, görevi bitince de yok olabilen seramikler yapılmaktadır (Çolakoğlu, 1998: 22).

Çağdaş sanat anlayışı ile birlikte yoğunluk kazanan disiplinlerarası ilişki, çağdaş seramik sanatının oluşumunda da kendini etkili bir şekilde göstermiştir. Sanatın farklı alanlarından birçok sanatçı bir ifade aracı olarak seramikten etkilenmiş ve uygulamalarında ana ve/veya yardımcı malzeme olarak seramik malzemesini kullanmışlardır. Çağdaş sanatın her alanından çok önemli sanatçılar bu seramik kullanımları sonucunda seramik sanatını da disiplinlerarasılık anlamında etkilemişler ve seramik alanına ayrı bir değer/anlam katmışlardır (Çevik, 2018: 13).

Seramik alanında bu gelişimlerin bir yansıması veya sonucu olarak tasarlama, şekillendirme, uygulama ve dekorlama yöntemleri de gelişme göstermiştir. Bu dekorlama yöntemlerinin ilk aşaması mühür baskılar olmasının çok ötesine geçerek günümüzde birçok farklı baskı tekniğinin yanı sıra dijital baskı yöntemleri de uygulanmaktadır.

\section{2. Çağdaş Sanatta Disiplinlerarası Yaklaşımlar}

21. yüzyıl geçmiş yıllarda sosyal, ekonomik ve kültürel anlamda yaşanan tüm olayların bir sentezini sunmaktadır. Toplumda var olduğu günden buyana sanatçı, bir kültür yaratıcısı konumunda içinde bulunduğu çağın aurasını yansıtan eserler ortaya koymuştur (Kayahan ve 


\section{ÇAĞDAŞ SERAMIKK SANATINDA BİR İFADE BİÇIMİ OLARAK SERİGRAFİ BASKI TEKNIGĞI VE BİREYSEL UYGULAMALAR}

Çevik,2020: 192).Toplumsal, ekonomik ve teknolojik olarak değişen dünya aracılığı ile sanatsal yaklaşımlarda da kökten bir değişim ve dönüşüm yaşanmıştır. Bu sürecin bilimsel ve teknolojik gelişmelere paralellik göstermesinin yanı sıra 21. yüzyıl insanının kendini, yakın ve uzak çevresini, doğayı, düşüncelerini, niyetlerini zaman ve mekân kavramlarının ötesinde tüm disiplinlerin birbiriyle yoğun, çok yönlü ve güçlü bir etkileşim içinde olduğuna işaret etmektedir. Özellikle plastik sanatlar alanında kurulan bu disiplinlerarası etkileşimin bir başlangıcı olarak çağdaş sanat anlayışında sanatçının bireysel, duygusal ve kurgusal ifadesini güçlendirebilecek her türlü malzemenin ve tekniğin kullanımına yönelik özgürlügün ve özgünlüğün vurgusu ön plandadır (Çevik, 2018:120).

Savaş'a göre disiplinlerarası kavramına eski Mısır ve Yunan Sanatından sonra Rönesans Sanatında rastlamaktayız. Rönesans döneminde hem sanat hem de bilim disiplinlerinin bir arada kullanılmaya başlandığı görülmektedir (Savaş, 2010: 6). Disiplinlerarası ilişki bakımından sanatçılar değerlendirilecek olursa özellikle malzeme açısından geleneksele bağlı kalmakta 1srarcı olmamaları bu sanatçıların ortak belirleyici özelliğidir. Bilindik sanat malzemelerin yanında günlük hayattaki sıradan malzemeleri üretimlerine dahil eden sanatçılar, kolaj, asamblaj ve fotomontaj gibi teknikler ile çalışmalarını ortaya koymaktadırlar.Üretilenler, sanata ve geleneğe karşı bir karakter taşıdıkları için ne heykel, ne resim belki ne de birer "sanat" yapıtıdırlar. Bu sanatçıların sanata karşıtlıklarının ifadesi aynı zamanda hazır nesne (readymade) sergilemeleriyle de ortaya çıkmaktadır. Hazır nesneler, meydana gelen şeyin ardındaki anlamla belirginleştiği için fikrin yani kavramın ortaya çıkmasıyla örtüşür ve bu da Kavramsal Sanat için belirleyici olur (Akgün, 2012: 24).

Hızla yaygınlaşarak uluslararası arenaya yayılan kavramsal sanat, 1960 sonrasında gelişen hemen tüm akımların yolunu açmıştır. Sanatın ne olduğuna dair yeni önermeler getiren ve yetenek yerine sınırsız yaratıcılık düşüncesini savunan Kavramsal Sanat, çok çeşitli akımlar/eğilimler/ oluşumlar halinde günümüze kadar uzanmış, günümüzde resim, heykel gibi daha geleneksel türlerin de kavramsallaşmasında rol oynamıştır (Antmen, 2008: 196). 21. yüzyılda artık, sanatsal üretimler, sanatçının kendisi ya da çevresi ile yüzleştiği, bu yüzleşmelerin farklı alanların işbirliğinde oluşan projeler ile ifade bulduğu, kültürel-psikolojik durumların enstalasyonlara dönüştüğü bir mecrada gerçekleştirilmektedir. Tasarımları/sanat eserleri için sürekli yeni medyalar ve yeni mecralar keşfetme kaygısı taşıyan sanatçı ya da tasarımcılar, pratik bir amaç doğrultusunda farklı konular üzerinde yeni anlamlar ve kurgular oluştururlar (Bingöl ve Bingöl, 2018: 123). Çağdaş sanat anlayışında ortaya çıkan yaklaşımlar ise sanat disiplinlerinin iç içe geçtiğini, önemli olanın estetik duyarlılık olduğunu ve ortaya 


\section{ÇAĞDAŞ SERAMIKK SANATINDA BİR İFADE BİÇİMİ OLARAK SERİGRAFİ BASKI TEKNIGĞI VE BİREYSEL UYGULAMALAR}

çıkan sanat nesnelerinde kullanılan malzemenin ne olduğundan çok içeriğin ne olduğunun önem kazandığını göstermiştir (Kılıç, 2005: 66).

\section{Bir İfade Biçimi Olarak Seramik Üzerine Uygulanan Serigrafi Baskı Tekniği}

Baskıresim, duygu ve düşüncenin kalıplar aracılığıyla başka bir yüzeye aktarımı ve birden fazla kopyanın elde edilebilirliği esasına dayanır (Fırınc1, 2013: 128). Çeşitli araç ve malzeme ile doğrudan veya kalıplar yapmak yolu ile kağıda veya benzeri malzeme üzerine, sanatçı tarafından yapılıp basılan resimlere özgün baskıresim denir (Aslıer, 1995: 110).

Kağıdın ve yazının bulunmasından sonra keşfedildiği bilinen baskıresimin ilk örneği M.S.868 yıllarında yapılmış olan 5 metrelik ünlü Diamond Sutra isimli çalışmadır. Budist inancına yönelik yapılmış Çinlilere ait ilk ağaç baskı denemesi olan bu çalışmanın ardından Doğu'da gelişen bu teknik Avrupa İle kurulan ticari bağlar neticesinde Batı'ya ulaşır. 15.yüzyıldan itibaren plastik sanatların içinde yer alan Özgün Baskıresim Sanatı, o tarihlerde çoğaltma tekniği olarak kullanılmaktadır. 1450'lerde matbaanın keşfinden sonra baskı süsleme ve resim alanında bağımsız bir yeni alana dönüşür(Akalan, 2000: 16-18;Ayan, 2007: 22-23). Albert Dürer, Rembrandt gibi teknikten yararlanan ressamlar ağaç baskı ve gravür tekniği ile eserler üretmekte, tekniğin çoğaltılabilir olma durumundan yararlanmaktadırlar. 17. yüzyılda taşbaskı, 19. yüzyılda ise elek baskının bulunmasıyla sanat dünyasında etkili bir yere sahip olan baskıresim sanatçılara, ulaş1labilirliği ve kendine özgü kuralları ile geleneksel ve çağdaş üretimlerin bir arada yapılabildiği eşsiz bir zemin sağlamaktadır.1960'lı yıllar baskı sanatının temel bir dönüşüm geçirdiği, tekniğin olanaklarını sonuna dek kullanma arayışlarının peşine düşüldüğü, aynı zamanda buna kültürel bir zemin arandığı yıllar olmuştur. Aynı zamanda dönemin tematik yönelmeleri, baskı sanatı içinde yeni teknik arayışları beraberinde getirmiştir. $\mathrm{Bu}$ yıllardan sonra baskı sanatı yan bir uğraş olmaktan çıkmış yaşamını buna adayan sanatçı kuşakları ortaya çıkmış ve 1980'lerden sonra piyasa olgusu ile çoğaltılabilirliğin bir değer olarak benimsenmesi baskı sanatına olan ilginin artmasını sağlamıştır (Esmer, 2011: 10-11).

Kullanılan malzemeye göre şekillenen baskıresim teknikleri genel anlamda dört gruba ayrılmaktadır: yüksek baskı, çukur baskı, düz baskı ve şablon baskı. Ağaç ve linol malzemeye oyulan tasarımın yüksek kısımlarında kalan boyaların kağıdın yüzeyine transfer edilmesi mantığına dayanan teknik yüksek baskı çeşididir. Bakır, çinko gibi malzemelere kazıyarak veya asitle indirgeyerek yapılan baskılar ise çukurda kalan boyanın alınması mantığı çerçevesinde çukur baskı olarak adlandırılmaktadırlar. Düz baskı ise Litografi taşının üzerine yağlı kalem ile çizilmesi ve boyanın su ve yağın itme-çekme prensibi doğrultusunda düz bir yüzeyden boyanın 


\section{ÇAĞDAŞ SERAMIKK SANATINDA BİR İFADE BİÇIMİ OLARAK SERİGRAFİ BASKI TEKNIGĞI VE BİREYSEL UYGULAMALAR}

alınması işlemidir. Şablon baskı türü içerisinde konumlandırılan serigrafi-ipek baskı (elek baskı) tekniği bu makalenin konusu dahilindedir. Baskıresim sanatçıları bu teknikleri tek başına kullanabildikleri gibi farklı teknikleri aynı yüzey üzerine uygulayarak karışı teknikle baskıresim çalışmaları da yapabilmektedir (Kayahan, 2019: 1136).

Serigrafi-ipek baskı, bir çerçeveye gerili, elek gibi gözenekli bir yüzeyde yazı, resim, çizim gibi çeşitli tasarımlarla açık ve kapalı alanların oluşturulması ve bunların üzerinden boya sıyırarak değişik yüzeylere basılması işlemidir. Bir başka tanımla, diğer baskı sistemleri ile yapılamayan ve baskı eleğinin desenli (resimli) alanlarının üzerinden rakle ile boya sıyırarak metal, ahşap, pvc, cam, porselen, deri, tekstil vb. mamul veya yarı mamul ürünler üzerine basılmasına serigrafi-ipek baskı denir (Pekmezci, 2001: 12).Bu bask1 yöntemi, benzeri bask1 teknikleri içinde ağaç baskı, metal baskı, taş baskı, ofset vb. gibi geçmişi en az bilinendir. Japonlar yüzyıllar önce bir bakıma bugünkü eleklerle yapılan baskının ilk örneklerini oluşturmuşlardır. Saf ipek dokumalı eleklerin kullanılması ile teknik çok büyük kullanım kolaylıkları kazanmıştır. 1915 yılında ilk fotografik yöntemin bulunması ile ipek baskı yeni bir hayat kazanmıştır (Pekmezci, 1992: 12).

Grafik temelli bir alan olarak değerlendirilebilecek olan baskıresim disiplinlerarası etkileşimlerin bir sonucu olarak farklı alanlarda da kullanılmaktadır. Resim ve grafik alanında uygulanan baskı tekniklerinin neredeyse tamamını seramik bünyeler üzerinde de kullanmak mümkündür. Ancak unutulmamalıdır ki bu teknikleri sırlı veya sırsız seramik yüzeylere uygulayabilmek için, seramik yüzeylerde kullanıma ve fırınlamaya uygun boyalar olmalıdırlar. Uygun boya seçimi yapılmazsa seramiğin fırınlanma aşamasında boyaların uçması veya yanması-kararması gibi istenmeyen durumlarla karşılaşılabilinir.

Seramik alanında baskı tekniklerinin tercih edilmesinin en önemli nedeni karmaşık ve detaylı dekorların baskı tekniklerinin olanaklarını kullanarak tekrar tekrar kolaylıkla uygulanabilmesidir. Diğer bir neden ise bir görüntünün birden fazla transfer etme olanağ 1 sayesinde hem endüstriyel hem de artistik uygulamalarda uygulayıcıya yeni ifade olanakları sağlamasındandır. Günümüzde bu uygulama olanaklarının seramik yüzeylerde kolaylıkla uygulanabilirliğinin sanatçılara sağladığı avantaj sayesinde gerekli olan tüm baskı malzemeleri büyük ölçekli fabrikasyon (endüstriyel) üretim yapan işletmelerin yanı sıra küçük ölçekli atölyeler içinde seramik ürünleri satan mağazalar aracılığı ile kolayca ulaşabilmek mümkündür. $\mathrm{Bu}$ kolay ulaşım ve ekonomik üretimlerin piyasaya sürülmesi sayesinde günümüzde seramik bünyelerde tamamlayıcı bir öğe halini almış ve seramik sanatçıları tarafından tercih edilen ve yaygın kullanılan teknikler arasına girmiştir.Bu baskı tekniğinde kullanılan en önemli malzeme ipektir. Serigrafi baskıda izlenilen uygulama yöntemi şöyledir; 


\title{
ÇAĞDAŞ SERAMIKK SANATINDA BİR İFADE BİÇİMİ OLARAK SERİGRAFİ BASKI TEKNİĞİ VE BİREYSEL UYGULAMALAR
}

-İpek gerilmiş çerçeve oluşturmak

-Oluşturulan ipek gerimli çerçeveye pozlandırma yapılabilmesi için emülsiyon uygulamak

-Emülsiyon uygulanmış kalıba pozitif film pozlandırmak

-Pozlandırılan kalıbı yıkayıp, kurutup baskıya hazır hale getirerek baskı makinesine bağlamak. (Öztürk, 2015: 82).

Seramik yüzeylerde serigrafi tekniğinin uygulanabilmesi süreci şu şekilde gerçekleşir:

\begin{abstract}
Bir çeşit şablon baskı türü olan serigrafide kalıp, ipeğin alüminyum veya ahşap çerçevelere gerilmesi ile oluşur. Gerilen eleğin üzerine emülsiyon çekilerek kurutulur. Daha sonra şeffaf bir kâğıda hazırlan şablon resim elek üzerine konularak 1şıklı masa üzerinde pozlanır. Pozlamadan sonra, elek yıkandığı zaman, şablonun olduğu siyah bölgeler dökülür ve desen elek üzerine geçirilmiş olur. Bu aşamadan sonra hazırlanan seramik boyaları seramik yüzeylere veya dekal kâğıtlara aktarılarak transfer gerçekleştirilir. Renkli bir baskı yapılmak istendiğinde ise her bir renk için ayrı ayrı kalıp hazırlamak gerekmektedir. $\mathrm{Bu}$ işlemler günümüzde bilgisayar programları ile yapılabilmekte ve resimdeki her bir renk kolaylıkla ayrılabilmektedir (Özgüven, 2017: 47).
\end{abstract}

Serigrafi baskıyı iki başlık altında toplamak mümkündür: Sanatsal amaçlı serigrafi;

Resim, grafik, baskı sanatçıları ve tasarımcılar, eserlerinin belirli sayıda çoğaltabilmek için, serigrafi baskı tekniğinden faydalanmaktadırlar. Pablo Picasso, Hanry Matisse, Victor Waserly, Türk sanatçılardan Bedri Rahmi Eyüpoğlu, Süleyman Saim Tekcan ve Hasan Pekmezci bu tekniği eserlerinde kullanmışlardır. Endüstriyel amaçlı serigrafi; Serigrafi tekniği endüstri ve reklamcılıkta yoğun bir şekilde kullanılmaktadır. Ambalaj paketleme fabrikalarında, her türlü malzemeye ve yüzeylere serigrafi baskı yapılabilmektedir. Seramik fabrikalarında karo ve fayans yüzeylere desen basımı, tekstil fabrikalarında kumaşların üzerine çeşitli motif ve süslemelerin basımı, elektronik endüstrisinde entegre devrelerin yüzey basımında serigrafi baskıdan faydalanılır. Reklamcılık alanında ise, her türlü tanıtım tabelası, piktografik işaretlerin çoğaltılması ve mekan tasarımlarında serigrafi baskı kullanılır (Tepecik, 2002: 111).

Porselen, seramik ve cam üzerine uygulanan sulu çıkartma (dekal) tekniği serigrafinin diğer bir uygulama çeşididir. Sulu çıkartma firınlanabilen yüksek dereceli boyalarla serigrafi baskı tekniğinden faydalanarak gerçekleştirilir. Grafik tasarımında desen oluşturulması, bu desenin porselen, seramik ya da cam gibi parlak ve sert yüzeylere kalıc1 şekilde uygulanması yöntemi belirli aşamalarla gerçekleşmektedir. İlk olarak desenin oluşturması ve bu deseni uygulanacak mamule uygun hale getirmesi gerekmektedir. Bu hazırlığa renk ayrımı denir. Renk ayrımı, tasarlanan desenin her renginin ayrı ayrı film tabakasına montajlı halde basılıp, film çıktısı alma işlemine denir. Bu işlem serigrafi baskı makinalarında her rengin ayrı basılabilmesi için gereklidir. Elde edilen filmler, pozlandırılmak üzere her rengin boyasının özelliğine ve film çıktısındaki tramtire uygunluğuna göre farklı ipek kalınlıklarına göre emülsiyon çekme işlemine 


\section{ÇAĞDAŞ SERAMIKK SANATINDA BİR İFADE BİÇİMİ OLARAK SERİGRAFİ BASKI TEKNIGĞI VE BİREYSEL UYGULAMALAR}

tabi tutulur. Emülsiyon çekimi yapılan ipek çerçeveler kurutulduktan sonra ipeğin ve emülsiyonun özelliklerine göre pozlandırılır. Serigrafi baskı işlemi bu kalıpların makinaya bağlanmasıyla ve baskı uygulanacak kâğıdın ve boyanın hazırlanmasıyla yapılabilmektedir. Serigrafi baskı makinalarına bağlanmış ipek kalıplarla yüksek derecede firınlanabilen seramik ve cam boyalarının ragle yardımıyla kâğıda baskısı ve son olarak çıkartmanın transferinin sağlanabilmesi için lak (vernik) baskısı işlemi baskıdaki son aşamadır. Üretilen sulu çıkartma, baskı sonrası mamule aktarımı (transferi) aşamasındadır. $\mathrm{Bu}$ aşamada çıkartma 11ık suda bekletilerek desen kâğıttan mamule aktarılır. Mamule ragle yardımıyla çıkartma yerleştirilir, kalan suyu alınır ve ürününün nihai görüntüsü için fırınlama işlemine geçilir. Fırınlama işlemi porselen, seramik ve cam ürünlerinde değişiklik gösterir. Bu değişiklik ürünün yapısıyla ilgilidir. Bazı durumlarda ise boya faktörü de fırınlama derecesini değiştirmektedir. Son aşamada fırınlanan ve belirli soğuma aşamasından geçen ürün, artık hazır durumdadır (Öztürk, 2015: 3-4).
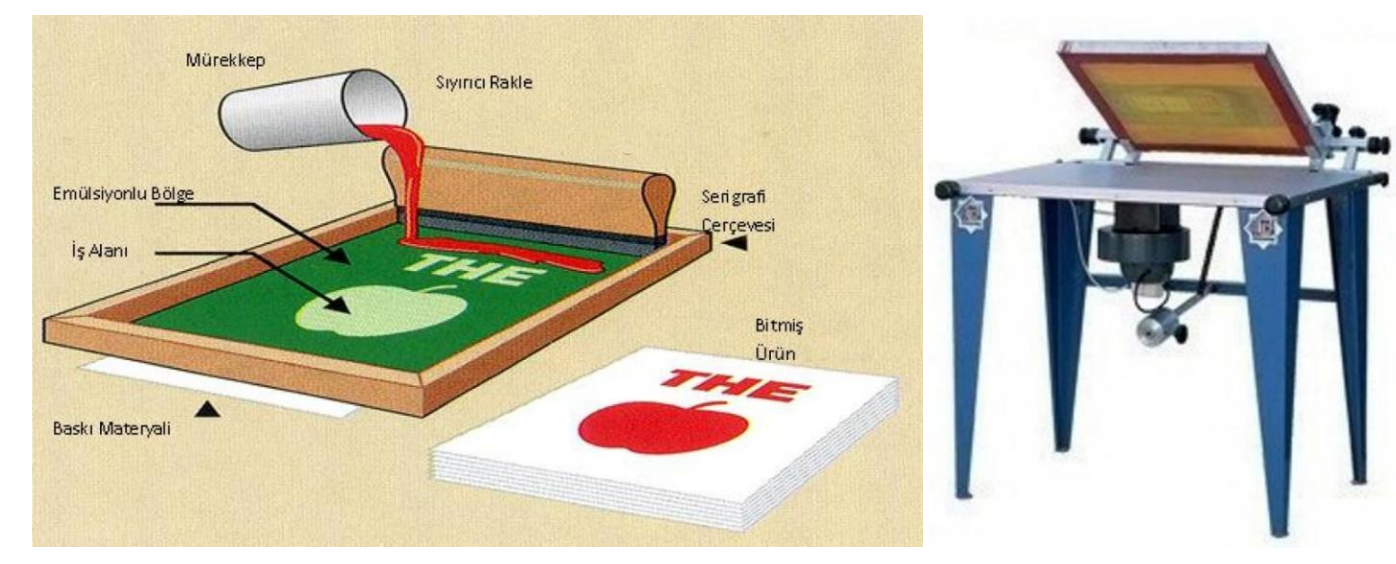

Serigrafi Bask1 Düzeneği Görseli (Aktr. Öztürk, 2015: 89) Şekil 1:

El Tezgâhı Bask1 Makinesi. (Aktr. Öztürk, 2015: 90) http://www.ultrateknik.com/manuel-eltezgah-.html Şekil 2:

Seramik endüstrisinde makineleşmenin getirdiği kolaylıklarla seramik dekorları çok daha kolay ve pratik bir biçimde yapılabilmektedir. Teknolojiyle birlikte yol arkadaşlığı yapan serigrafi tekniğinin günümüzde dijital bask1 ile yoluna devam etmektedir. Günümüzdeki kullanım alanıyla dijital baskı seramikte devrim niteliği taşımaktadır (Esgin, 2014: 83). Kalay’a göre (2009:89) serigrafi tekniği ile uygulama yapılmış olan seramik çalışmaların firınlama dereceleri, kullanılan boyaların pişirim dereceleri göz önüne alınarak belirlenmelidir. Genel olarak sir üstü boyalar düşük derece pişirim gerektirmektedirler. Pişirim derecesini doğru bir şekilde belirleyebilmek için deneme pişirimler yapılmasında fayda vardır. Pişirim sırasında 


\section{ÇAĞDAŞ SERAMIKK SANATINDA BİR İFADE BİÇİMİ OLARAK SERİGRAFİ BASKI TEKNİĞİ VE BİREYSEL UYGULAMALAR}

oluşabilecek zehirli gaz çıkışlarına karşı gerekli önlemler alınmalıdır. Sevim’e (2003:163) göre; "Serigrafi dekorları genel olarak boya ve sırların çeşitli işlemlerden sonra çok ince metal veya özel dokulu naylon ya da ipek elek üzerinde hazırlanmış desenlerden dekorlanacak yüzeyler üzerine direkt ya da indirek yollarla aktarılması işlemidir.” şeklindeki tanımı serigrafinin seramikteki kullanımına işaret etmektedir.

\section{Bireysel Söylemler; Rasim Bağırlı}

Tasarımcılar, sanatçılar geleneksel anlamda var olan teknikleri günümüzde yeni teknolojiler ile uyumlandırarak kullanmaktadır. Serigrafi tekniği de teknoloji ile gelişmiş olsa da, günümüzde geleneksel anlamda kullanılmaya devam etmektedir. 1960 sonras1 sanat ve tasarım içerisinde serigrafi tekniği tasarımcılar ve sanatçılar tarafından oldukça tercih edilen bir üretim aracı olmuştur. Serigrafi tekniği ile butik iş üretimlerinde bulunan tasarımcıların yanı sıra baskı tekniklerinin sınırlarını zorlayan üretimlerde bulunan sanatçılarda mevcuttur. Kimi zaman basacağı yüzeyi değiştiren sanatçılar kimi zaman da basmak için kullanacağ1 yüzeyde değişiklikler yapmışlardır (Bayram, 2019:iv). Akademisyen sanatçı Rasim Bağırlı seramik uygulamalarında renk çeşitliliğinin sağlanmasında kolaylık oluşturması bakımından bir ifade biçimi olarak serigrafi baskı tekniğini iki veya üç boyutlu çalışmalarında tercih etmektedir.

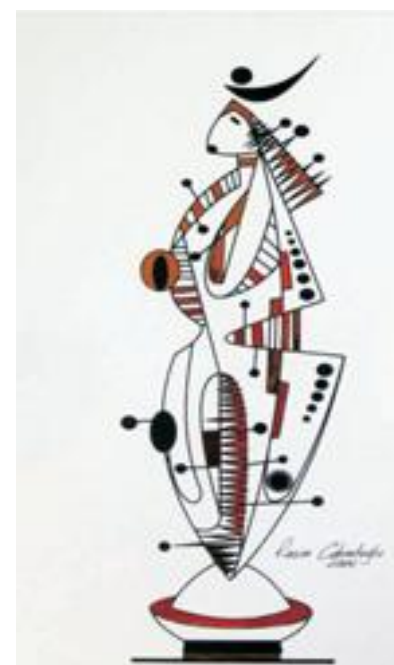

Rasim Bağırlı, İzler/İzlenimler Serisi, Seramik Üzeri Serigrafi, 20x30 cm Şekil 3

Rasim Bağırlı, İzler/İzlenimler Serisi, Seramik Üzeri Serigrafi, 20x30 cm Şekil 4

Şekil 3-4-5-6-7-8-9 ve 10'da İzler/İzlenimler Serisi Bağırlı'nın kendi özel yaşamından ve çevresinde gözlemlediği yaşamlardan yansımaları kapsamaktadır. Bu seriye ait çalışmalarda 


\section{ÇAĞDAŞ SERAMIKK SANATINDA BİR İFADE BİÇİMİ OLARAK SERİGRAFİ BASKI TEKNIGĞI VE BİREYSEL UYGULAMALAR}

özellikle renk tercihi siyah ve kırmızı ile sınırlı tutularak, kompozisyonlardaki devinime dikkat çekmek istenmiştir. Alexander Calder ve Joan Miro'nun eserlerini çağrıştıran form ve biçimler ile sanatçı kendi özgün tasarımını ortaya koymuştur.

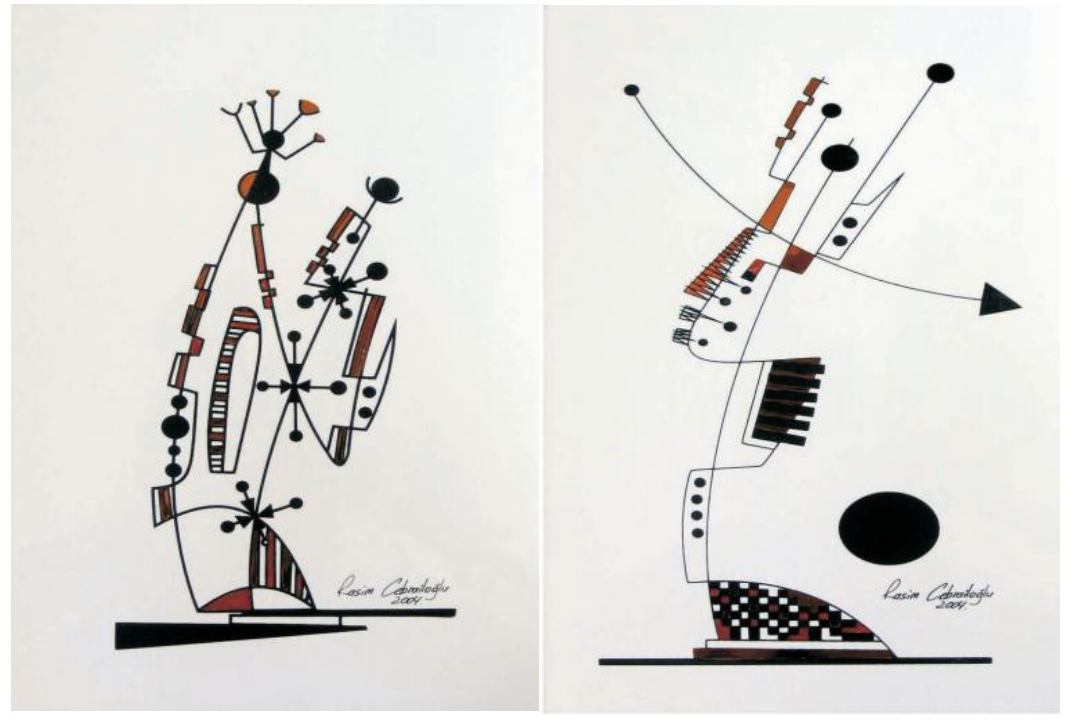

Rasim Bağırlı, İzler/İzlenimler Serisi, Seramik Üzeri Serigrafi, 20x30 cm Şekil 5 Rasim Bağırlı, İzler/İzlenimler Serisi, Seramik Üzeri Serigrafi, 20x30 cm Şekil 6

Özelikle Calder'in ilk durağan ve mobil çalışmalarında kozmik imgeler ve düzlemlere ait dengenin kontrolü onun form anlayışına ilham veren düşünceleridir (Fineberg, 2014: 49-52). Evrenin matematiksel yasalarını yansıtma girişimleri ve bu hareketin oluşunun bir güç tarafından dengede tutulması ile gerçekleştiğinin farkındadır ve bu farkındalıkla hareketli (mobil) kompozisyonlar oluşturmasıdır (Omak, 2012: 30). Bu mobillerin her bir parçası, değişik biçimler oluşturarak, tıpkı gezegenler gibi, farklı yerçekimi ve denge merkezleri çevresindeki ilişkileri doğrultusunda yeniden tanımlanan hareketler oluşturmasıdır (Fineberg, 2014: 52-53). Bağırlı, tasarımlarında Calder'in kozmik imgelerinin figüratif bir yorumlamasını yapmış gibidir. Düz beyaz seramik zemin evreninde mobil figürlerin dinamik duruşları görülmektedir. "Ögelerin bulunduğu alandaki konuşmaların net bir şekilde algılanabilmesi için uygulamanın bazı yerlerinin nefes alması gerekmektedir. Nefes alınan, sessizlik bölgeleri boşluğu tanımlar. Boşluk ve doluluk arasındaki denge, bir çalışmanın başarısını olumlu ya da olumsuz anlamda etkileyebilecek bir faktördür” (Pazarlığlu, B. 2018: 53). Bağırlı'nın çalışmalarında boşluk ve doluluğun dengeli bir biçimde yerleştirildiği görülmektedir. Çalışmalardaki boş alanlar, çizgi ve lekesel değerlerle anlatılmak istenilen duygu ve düşüncelerin daha net bir biçimde okunabilmesini sağlamakta ve etkili bir görsellik oluşturmaktadır. 


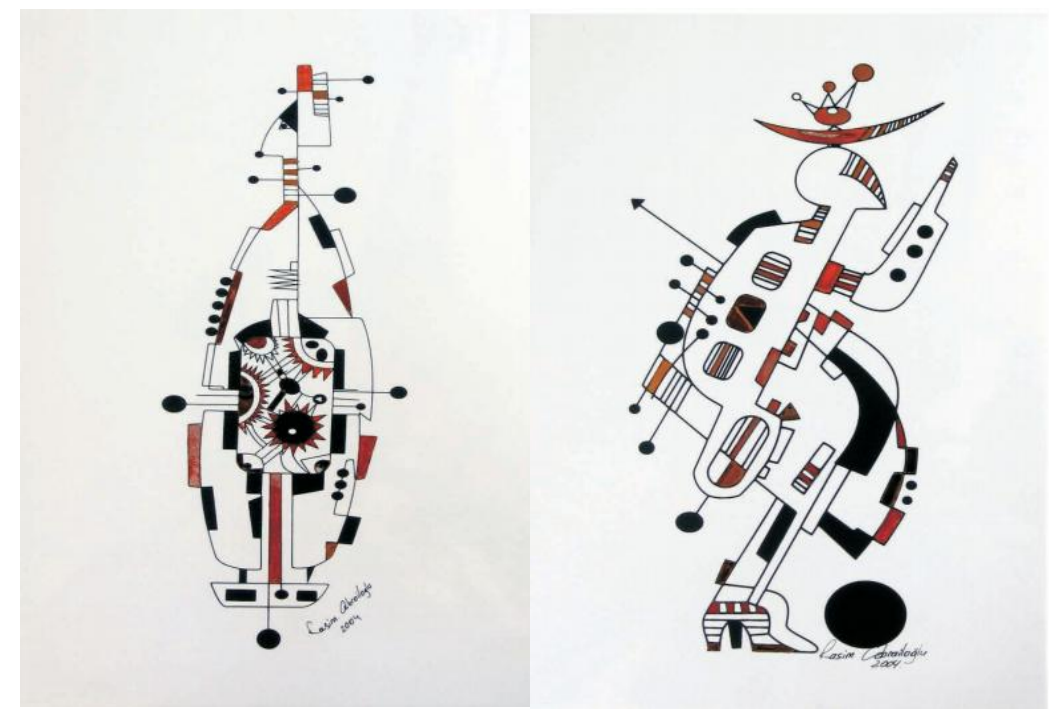

Rasim Bağırlı, İzler/İzlenimler Serisi, Seramik Üzeri Serigrafi, 20x30 cm Şekil 7

Rasim Bağırlı, İzler/İzlenimler Serisi, Seramik Üzeri Serigrafi, 20x30 cm Şekil 8

Özellikle Görsel 3-4 ve 8' de soyut figüratif unsurlar dikkat çekmektedir. Figürler nokta ve çizgilerin ahenkli birleşimi ile açık koyu dengesinin kurulumu üzerine şekillendirilmiştir. Özellikle kadın figürlerinin kıyafetlerinde çeşitli motif unsurları görülmektedir. Siyah, kırmızı ve beyaz rengin dengeli bir bütünlüğü söz konusudur.

Şekil 5-6 ve 7'de soyut kompozisyonlar dikkat çekmektedir. Bu durum, Miro'nun tuvale lekeler sürüp, onları dağıtarak yeni bir görsel etki yaratması ve bu yapıtlarında lekelerin derinliği olmayan yüzeyde boşlukta sallanmasını ifade eder (Lynton, 2004: 174-175).

Şekil 9 ve 10 'da tasavvuf felsefesinden izler gözlenmekte ve derviş siluetleri dikkat çekmektedir. Özellikle bu iki düzenlemede dervişlerin kıyafetlerinin üzerinde siyah-kırmızı renk vurgusu ile yapılan istiflemelerle gönül doluluğunun çağrışımlarına odaklanılmıştır. Bağırlı uzun süreler tasavvuf felesefesini araştırmış ve bu temel konunun çevresinde iki veya üç boyutlu özgün seramik üretimlerinde bulunmuştur. 


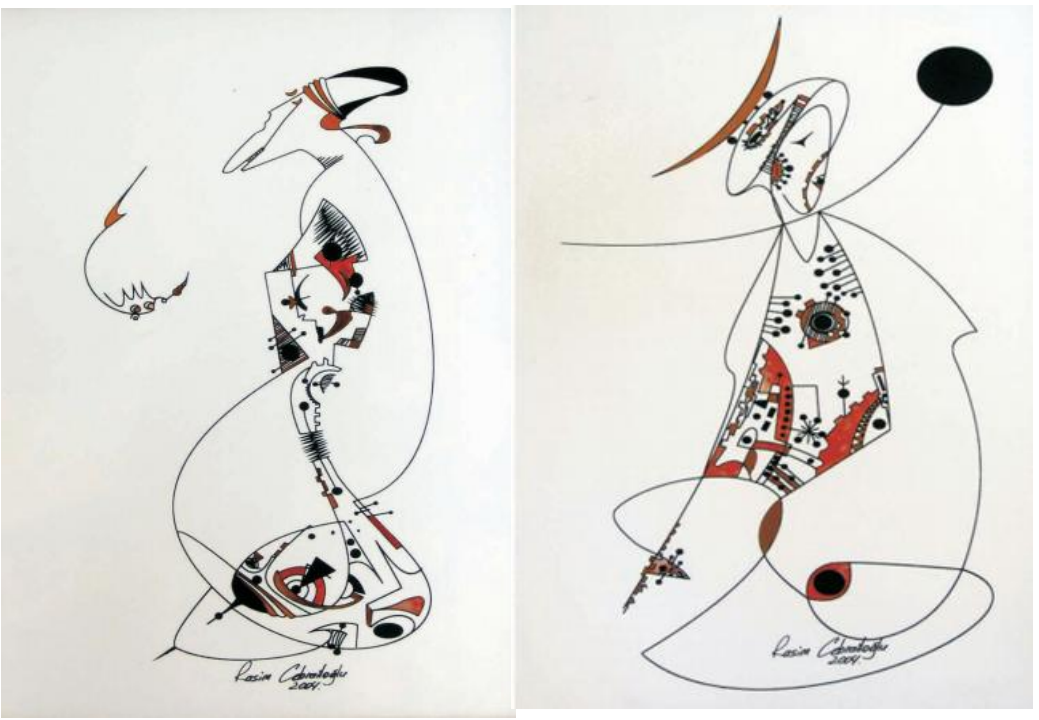

Rasim Bağırlı, İzler/İzlenimler Serisi, Seramik Üzeri Serigrafi, 20x30 cm Şekil 9 Rasim Bağırlı, İzler/İzlenimler Serisi, Seramik Üzeri Serigrafi, 20x30 cm Şekil 10

Bağırlı'nın Şekil 3-4-5-6-7-8-9 ve 10'da oluşturulan İzler/İzlenimler Serisi'nin neredeyse tamamında yer alan kompozisyonlarda bir ritim duygusu hissedilmektedir. Kompozisyonların arka mekânının bilinçli biçimde tam olarak oluşturulmama durumu onun zamandan ve mekândan ayrıştırılmış/arındırılmış bir anlam kazanmasını sağlamıştır. Bu durum kompozisyonlarda 1şık ve gölgenin de kullanılmamasıyla pekiştirilmiştir. Özellikle seramik üzerine serigrafi tekniği kullanılarak ortaya konulan bu üretimlerde grafiksel olarak yalın ancak güçlü bir anlatım sağlanmıştır.

\section{SONUÇ VE DEĞERLENDIRMELER}

İnsanlık tarihinde oldukça eski zamana uzanan ilk seramik üretimlerde bile günümüzde bir gereklilik olarak görülmeyen naif bir dekorlama unsuru onun ayrılmaz bir parçasıydı. Bu durum zamansal süreçte elle boyama tekniklerinin geliştirilerek teknolojinin yeni olanakları ile yeni baskı tekniklerinin denenmesine ve uygulanmasına imkân sağlamıştır. Günümüzde özellikle sanatın her alanında etkili olan disiplinlerarası etkileşimler ve kavramsal süreç konumalzeme çeşitliliğinin yanı sıra yeni alternatif üretim olanaklarını da beraberinde getirmiştir.

$\mathrm{Bu}$ açıdan değerlendirildiğinde baskı tekniklerinin uygulama kolaylıkları ve baskı kalitelerinin artması seramik bünyelerde de başarılı sonuçlar elde edilmesine olanak tanımıştır. Sanatçılar üretimlerinde sık sık kullandıkları bir dekorlama unsuru olan serigrafinin sır üstü veya sırsız yüzeylerde kullanımı sayesinde, özgün üretimlerinde renk, doku, kompozisyon vb. 


\section{ÇAĞDAŞ SERAMIKK SANATINDA BİR İFADE BİÇİMİ OLARAK SERİGRAFİ BASKI TEKNIGĞI VE BİREYSEL UYGULAMALAR}

farklı uygulama olanaklarını deneyimlemektedirler. Unutulmamalıdır ki, baskı alanının gelişim süreci şimdi ile sınırlı değildir ve her an gelişmeye açık bir alan olarak kişisel üretimlerin yanı sıra özellikle seri üretimlerde de kullanım kolaylığı ve ürünlere kazandırmış olduğu estetik katkıdan dolayı öncelikle tercih edilir bir yöntem olmaktadır.

\section{Kaynakça}

Akalan, G., (2000), Gravür, Kale Seramik Sanat Yayınları,İstanbul.

Akgün, A. S., (2012), Modern Kaygılar; 20. Yüzyıl Sanatında Hazır Nesne Kullanımı ve Tüketim Toplumuna Eleştirel Bir Bakış, Mimar Sinan Güzel Sanatlar Üniversitesi, Sosyal Bilimler Enstitüsü, İstanbul.

Antmen, A., (2008), 20.Yüzyıl Batı Sanatında Akımlar, Sel Yayıncılık, İstanbul.

Arcasoy, A., (1998), Seramik Teknolojisi, Marmara Üniversitesi Yayınları, İstanbul.

Aslier, M., (1995), Mustafa Aslıer, Bilim Sanat Galerisi, İstanbul.

Ayan, M., (2007), Sosyolojik Açıdan Özgün Baskıresim Sanatının Bugünkü Durumu İle İlgili Profesyonel Sanatçıların Görüşlerinin İncelenmesi, Marmara Üniversitesi, Eğitim Bilimleri Enstitüsü, İstanbul.

Bayram, M., (2019), Serigrafi Tekniğinin 1960 Sonrası Grafik Sanatına Yansımaları, Selçuk Üniversitesi, Sosyal Bilimler Enstitüsü, Konya

Bingöl, M. ve Bingöl, F., (2018). "Bilimsel ve Teknolojik Gelişmelerden İlham Alan Sanatlar", Asos Journal, Y. 6, S. 84, s. 106-127.

Çevik, N. (2010), “Çağdaş Seramik Sanatında Resimsel Yönelimler”, Gazi Üniversitesi Güzel Sanatlar Fakültesi Sanat ve Tasarım Dergisi, C.1, S. 6, s.35-45.

Çevik, N., (2015),“Avrupa Seramik Sanatında Endüstrileşme Süreci ve Cumhuriyet Sonrası Türk Seramik Sanatına Yansımaları", Gazi Üniversitesi Güzel Sanatlar Fakültesi Sanat ve Tasarım Dergisi, S.16, s.77-95.

Çevik, N., (2018), "Disiplinler Arası Etkileşimler Kapsamında Alternatif Malzemeler ve Seramik-Baskı Resim Yakınlaşmaları Üzerine Bireysel Uygulamalar", Ankara Hacı Bayram Veli Üniversitesi Güzel Sanatlar Fakültesi Sanat ve Tasarım Dergisi, S. 22, s. 111-133.

Çolakoğlu, H., (1998),“Günümüz Seramik Sanatı ve Konumu”, Türkiye'de Sanat Plastik Sanatlar Dergisi, S.33.

Erman, O. D., (2019),“Antik Çağdan Günümüze Seramik Kültürü ve Sanatında Doğurganlık Kavramı”, Ankara Hacı Bayram Veli Üniversitesi Güzel Sanatlar Fakültesi Sanat ve Tasarım Dergisi, S.24, s. 143-169.

Esgin, Ö., (2014), Siyah Figür ve Kırmızı Figür Tekniğinin Serigrafi İle Seramik Form Yüzeylerinde Uygulanması, Süleyman Demirel Üniversitesi, Güzel Sanatlar Enstitüsü, Isparta.

Esmer, H., (2011), Türkiye'de Baskı Resme Bakmak, Anadolu Üniversitesi Basımevi,Eskiş̧ehir.

Fırıncı, M., (2013), "Dijital Çağda Geleneksel Baskı Resim ve Teknikler Arası Geçiş (Melezleşme)", Anadolu Üniversitesi Sanat ve Tasarım Dergisi, Y. 4, S. 4, s. 127-135. 


\section{ÇAĞDAŞ SERAMIKK SANATINDA BİR İFADE BİÇİMİ OLARAK SERİGRAFİ BASKI TEKNIGĞI VE BİREYSEL UYGULAMALAR}

Fineberg, J., (2014), 1940’tan Günümüze Sanat, Karakalem Kitabevi Yayınları, İstanbul.

Kalay, L., (2009), Seramik Yüzeylerde Kullanılan Baskı Teknikleri ve Uygulamaları, Dokuz Eylül Üniversitesi, Güzel Sanatlar Enstitüsü, İzmir.

Kayahan, Z. ve Çevik, N. (2020). "Çağdaş Sanatta Bir Yansıma/YansıtmaSorunsalı Olarak Otoportre ve "Ben" Kavramı Üzerine Bireysel Söylemler", Ankara Hacı Bayram Veli Üniversitesi Güzel Sanatlar Fakültesi Sanat ve Tasarım Dergisi, S. 25,191-213.

Kayahan, Z., (2019), "Disiplinlerarası Süreçte "Resim-Baskıresim Yakınlaşmaları" Üzerine Bireysel Söylemler", İdil, S. 61, s. 1133-1147.

Kılıç Kapar, S., (2005), "Yaratmak Üzerine”, Rh+ Plastik Sanatlar Dergisi, S. 20.

Lynton, N., (2004), Modern Sanatın Öyküsü, Remzi Kitabevi, İstanbul.

Omak, N. S., (2012), 1960 Sonrası Heykel Sanatı ve Yeni Gerçekçilik, Dokuz Eylül Üniversitesi, Güzel Sanatlar Enstitüsü, İzmir.

Özel, V., (2007), Plastik Sanatlarda Disiplinlerarası Etkileşimler ve Seramik Sanatına Yansımas1, Anadolu Üniversitesi, Sosyal Bilimler Enstitüsü, Eskişehir.

Özgüven, S., (2017), Seramik Sanatında Dijital Uygulamalar, Hacettepe Üniversitesi, Güzel Sanatlar Enstitüsü, Ankara.

Öztürk, Ş., (2015), Desenin Oluşturulması ve Porselen, Seramik, Cam Ürünlerine Uygulanmas1, Arel Üniversitesi, Sosyal Bilimler Enstitüsü, İstanbul.

Pazarlığlu, B. M., (2018), “Hacmin Odağında Temel Tasarım Uygulamaları”, Akdeniz Üniversitesi Güzel Sanatlar Fakültesi Akdeniz Sanat Dergisi,S. 22, C. 12, s. 39-62.

Pekmezci, H., (1992), Tüm Yönleri İle Serigrafi İpekbaskı, İlke Yayınları,Ankara.

Pekmezci, H., (2001), Serigrafi, Milli Eğitim Bakanlığı Yayınları, Ankara.

Savaş, A. R., (2010),Disiplinlerarası Sanat Etkileşimlerinin Seramik Sanatı ve Eğitimine Etkileri, Gazi Üniversitesi, Eğitim Bilimleri Enstitüsü, Ankara.

Sevim, S. S., (2003), Seramik Dekorları, Anadolu Üniversitesi Yayınları, Eskişehir.

Sönmez, N., (2002), “Nesne, Sanatçı ve Seramik Sanatı İlişkisi”, Anadolu Sanat Dergisi, S. 13, s.175-183.

Tepecik, A., (2002), Grafik Sanatlar / Tarih - Tasarım - Teknoloji, Sistem Ofset Yayıncılık, Ankara.

Yardımcı, İ., (1993), Anadolu'da Başlangıcından Günümüze Seramik-Metal Teknik ve Biçim Etkileşimleri, Anadolu Üniversitesi, Sosyal Bilimler Enstitüsü, Eskişehir. 